\begin{tabular}{|l|c|c|c|c|}
\hline \multicolumn{1}{|c|}{ Submission } & Review Process & Revised & Accepted & Published \\
\hline $28-06-2020$ & $29-06$ s/d 30-07-2020 & $25-08-2020$ & $27-08-2020$ & $28-08-2020$ \\
\hline
\end{tabular}

Published by: Politik Islam UIN Raden Fatah Palembang

\title{
Kiai dan Politik: Analisis Peran Kiai Kecamatan SP Padang dalam Pilkada OKI tahun 2018
}

\author{
Nurpita Sari \\ Fakultas Adab dan Humaniora Universitas Islam Negeri Raden Fatah Palembang \\ Email: Nurpitasari1654300027@gmail.com
}

\begin{abstract}
This study discusses the kiai interaction in local elections. This kiai interaction can influence people's choice. The kiai's involvement can not only be seen from one factor (the kiai as a religious leader / figure), but a kiai who has many faces (multi-face) which reflects the complexity or diversity of the Kiai's perspective in politics.

The formulation of the problem in this study are first, what is the form of Kiai's interaction pattern in the OKI local election in SP.Padang District. Second, what are the factors that make Kiai involved in the Ogan Komering Ilir local election.

The method in this research uses a literature study approach and case studies to answer the problem formulation. The data study technique was carried out with books that were relevant to the research and interviews conducted with one of the communities and kiai in the SP. PADANG Ogan Komering Ilir

The results of this study indicate that the kiai's interaction can be seen for the first time, seen from how the support for certain political parties is supported by providing behind-the-scenes support. The kiai initiated his political vision and mission. In many branches the kiai gave approval when the pesantren was made into a political sphere. Second, the kiai were the actors. Namely kiai who join certain political parties and become the success team of candidates for Regent and Deputy Regent. Third, charismatic leaders are able to play an important role in creating fourth change, Kiai as local elites who are influential in providing support.
\end{abstract}


Keywords: local election, cleric, the role of cleric

\begin{abstract}
ABSTRAK
Penelitian ini membahas tentang keterlibatan kiai dalam pilkada OKI di kecamatan SP Padang, keterlibatan kiai ini bisa mempengaruhi pilihan masyarakat .keterlibatan kiai, tidak hanya dapat dilihat dari satu faktor saja (kiai sebagai pemuka/tokoh agama), melainkan kiai mempunyai banyak wajah (multi faces) yang mencerminkan kompleksitas atau keragaman cara pandang Kiai dalam berpolitik .

Adapun rumusan masalah dalam penelitian ini adalah pertama, Bagaimana bentuk pola keterlibatan Kiai dalam Pilkada Kabupaten OKI di Kecamatan SP.Padang.Kedua Faktor apa saja yang menjadikan Kiai terlibat dalam Pilkada 2018 Kabupaten OKI di Kecamatan SP.Padang

Metode dalam penelitian ini menggunakan pendekatan studi pustaka dan studi kasus untuk menjawab rumusan masalah. Tekhnik pengumpulan data dilakukan dengan buku yang relevan dengan penelitian dan dengan wawancara yang dilakukan kepada salah satu masyarakat dan kiai kiai yang ada di Kecamatan SP.PADANG KAB OKI.

Hasil penelitian ini menunjukan bahwa, keterlibatan kiai dapat dilihat pertama, Dilihat dari bagaimana kekuatan pendukung partai politik tertentu dengan cara memberikan dukungan dibalik layar. Kiai menginisiasikan visi dan missi politiknya. Pada banyak cabang kiai memberikan persetujuan ketika pesantren dijadikan ranah politik.Kedua, kiai sebagai aktor. Yaitu kiai yang masuk dalam partai politik tertentu dan menjadi tim sukses pasangan calon Bupati dan Wakil Bupati.Ketiga, pemipin karismatik mampu memainkan peran penting dalam menciptakan perubaha.kempat, Kiai sebagai elit lokal mempunyai karakteristik tersendiri dalam memberi dukungan.
\end{abstract}

Keywords: pilkada, kiai, peran kiai

\title{
PENDAHULUAN
}

Peranan tokoh dalam sebuah partai sangat menentukan konstituen dalam pemilu apalagi tokoh tersebut menjadi panutan banyak orang atau minimal di puja karena ide-idenya atau hanya bermodal kharisma yang dimiliki. Maka tak hayal apabila banyak partai politik yang berebutan menawarkan seorang tokoh dalam kepengurusan partai. Bahkan di angkat dalam kepengurusan partai dan diminta untuk merestui partai tersebut dengan harapan 
memperoleh suara dari para konstituen yang memiliki hubungan emosional dengan sang tokoh. Bentuk kongkrit dari ketokohannya adalah ikut dalam mendeklarasikan sekaligus duduk dalam kepengurusan elite partainya.

Dalam suatu masyarakat peran elite agama dan elite penguasa cukup mempengaruhi kehidupan baik di bidang sosial, ekonomi maupun politik. Kelompok tersebut antaralain aparat pemerintahan dan tokoh masyarakat. Salah satu tokoh masyarakat yang memiliki peran penting dalam bidang politik adalah kiai.

Kiai, menurut Zamakhsyari Dhofier merupakan gelar yang diberikan oleh masyarakat kepada ahli agama isalam yang memiliki atau menjadi pimpinan pesantran dan megajar kitab- kitab klasik kepada para santrinya. Kiai adalah tokoh yang mempunyai posisi yang strategis dan sentral dalam masyarakat. Posisi mereka terkait dengan kedudukannya sebagai orang terdidik dan kaya dalam masyarakat. Sebagai elite terdidik kiai memberikan pengetahuan islam kepada para penduduk desa. Dan pesantren sebagai lembaga pendidikan islam tradisional adalah sarana penting untuk melakukan transfer pengetahuan terhadap masyarakat desa tersebut. Dengan kekayaan yang dimilikinya kiai menjadi patron kepada siapa banyak penduduk desa bergantung. Posisi sentral kiai dapat dilihat dalam pola patronase ini, terutama kalau pola ini menghubungkan dan mengikat kiai dengan para santri atau siswanya. (Dirjasanjoto, 1989)

Sebagai pemimpin islam informal, kiai adalah orang yang diyakini penduduk desa mempunyai otoritas yang sangat besar dan kharismatik. Hal ini karena kiai adalah orang suci yang dianggrahi berkah, karena tipe otoritasini berada di luar dunia kehidupan rutin dan profan sehari-hari. Martin Van Bruinessen menyatakan bahwa kiai memainkan peranan yang lebih sekedar seorang guru. Dia bertindak sebagai seorang pembimbing spritual bagi mereka yang taat dan pemberi nasehat dalam masalah kehidupan pribadi mereka,memimpin ritual-ritual penting serta membacakan do'a pada berbagai acara penting. Banyak juga kiai jawa yang mempunyai kemampuan pengelihatan batin dan ilmu kesaktian tertentu, mereka bertindak sebagai orang yang dapat melakukan penyembuhan spritual dan mengusir roh jahat, membuat jimat-jimat atau mengajarkan berbagai teknik kekebalan tubuh. (Bruinessen, 1994)

Peranan kiai dalam politik selalu menarik untuk dibahas. Hal ini dikarenakan, studi tentang kiai tidak hanya dapat dilihat dari satu faktor saja (kiai sebagai pemuka/tokoh agama), melainkan kiai mempunyai banyak wajah (multi faces) yang mencerminkan kompleksitas atau keragaman cara pandang Kiai dalam berpolitik. Keterlibatan para kiai dalam proses Pemilihan Kepala Daerah secara langsung tidak bisa dihindarkan, karena mereka adalah potensi lokal dalam lingkungan pesantrean dan lingkungan masyarakat yang dapat memberikan konstribusi atau memeberi warna tersendiri bagi perpolitikan di tingkat daerah.

Pada saat ini tidak dapat di pungkiri bahwa peran tokoh dalam sebuah partai 
sangat menentukan pemilihan konstituen dalam pemilu apalagi tokoh tersebut menjadi panutan banyak orang atau minimal di puja karena ide-idenya atau hanya bermodal kharisma yang dimiliki. Maka dari itu banyak partai politik yang berebutan menawarkan seorang tokoh dalam kepengurusan partai. Bahkan di dalam kepengurusan partai dan diminta untuk merestui partai tersebut dengan harapan memperoleh suara dari para konstituen yang memiliki hubungan emosional dengan sang tokoh. Bentuk kongkrit dari ketokohannya adalah ikut dalam mendeklarasikan sekaligus duduk dalam kepengurusan elite partainya. Dalam suatu masyarakat peran elite agama dan elite penguasa cukup mempengaruhi kehidupan baik di bidang sosial, ekonomi maupun politik. Kelompok tersebut antara lain aparat pemerintah dan tokoh masyarakat. Salah satu tokoh masyarakat yang memiliki peran penting dalam bidang politik adalah kiai. (Dhofier, 2010).

Kiai adalah tokoh yang mempunyai posisi yang strategis dan sentral dalam masyarakat. Posisi mereka itu terkait dengan kedudukannya sebagai orang terdidik dalam masyarakat. Sebagai elite terdidik kiai memberikan pengetahuan Islam kepada para penduduk desa. Dan pesantren sebagai lembaga pendidikan Islam tradisional adalah sarana penting untuk melakukan transfer pengetahuan terhadap masyarakat desa tersebut. (Herman, 2013) Dengan kekayaan yang dimilikinya kiai menjadi patron kepada siapa banyak penduduk desa bergantung. Posisi sentral kiai dapat dilihat dalam pola patronase ini, terutama kalau pola ini menghubungkan dan mengikat kiai dengan para santri atau siswanya. Sebagai pemimpin Islam informal, kiai adalah orang yang diyakini penduduk desa mempunyai otoritas yang sangat besar dan kharismatik. Hal ini karena kiai adalah orang suci yang dianugrahi berkah, karena tipe otoritas ini berada di luar dunia kehidupan rutin dan profan sehari-hari, Sehingga kiai dipandang mempunyai kelebihan yang luar biasa yang membuat kepemimpinannya diakui secara umum. Di samping kelebihan personalnya otoritas kiai dan hubungan akrabnya dengan anggota masyarakat telah di bentuk oleh kepedulian dan otoritasnya pada kepentingankepentingan umat Islam.

Posisi kiai telah memainkan peran peratara bagi umat Islam dengan memberi mereka pemahaman apa yang terjadi di tingkat nasional. Para penduduk desa yang biasa menyebut diri mereka orang awam, sadar bahwa mereka tidak memiliki pengetahuan yang cukup untuk mengetahui peristiwa-peristiwa yang terjadi di tingkat nasional. Hubungan yang dekat antara penduduk desa tersebut dengan kiai menempatkan kiai pada posisi sebagai penerjemah yang memberikan penjelasan dalam konteks agama dan mengklarifikasi berbagai masalah bangsa pada umumnya. Posisi menonjol para kiai ini lebih tampak ketika partai politik secara intens memasuki Peran kiai secara ideal adalah yang bersih dari politik praktis dan mengembalikan posisi sebagai sebagai organisasi sosial keagamaan yang mengedepankan kegiatan keagamaan, pendidikan, sosial, ekonomi, serta mengembalikan ulama sebagai pemimpin yang sebenarnya. Tetapi pada kenyataannya posisi kiai dimanfaatkan oleh elite politik. Dengan tetap eksisnya peran kiai di pedesaan Kabupaten Ogan Komering Ilir, menimbulkan motivasi bagi penulis 
untuk mengadakan penelitian tentang keterlibatan Politik Kiai di Pedesaan.

Studi tentang kiai senantiasa berhubungan erat dengan power dan faktor penetu dalam kehidupan sosial, ekonomi dan politik dalam masyarakat. Dikursus tentang kiai ada dua pendapat yang berkembang saat ini, Pertama, pendapat menyatakan bahwa kiai adalah tokoh agama yang konservatif dan sulit menerima pembaharuan,sebagaimana hasil penelitian pendapat Geertz, peranan kiai hanya sekedar Cultural broker, kedua, pendapat yang menyatakan bahwa kiai adalah elit dinamis,rasional,dan mau menerima pembaharuan sebagaimana hasil penelitian Dhofier dan Horikhosi. Bahkan hasil dari penelitian Dirjosanyoto dan Endang Turmudi menyatakan bahwa kiai adalah tokoh agama sekaligus tokoh politik. (Horikhosi, 1987)

Secara umum keterlibatan kiai dalam Pilkada di Kabupaten Ogan Komering Ilir tahun 2018 dapat dibagi menjadi dua.Pertama kiai sebagai aktor. Yaitu kiai yang masuk dalam partai politik tertentu dan menjadi tim sukses pasangan calon Bupati dan Wakil Bupati. Aktivitas politik yang mereka lakukan adalah dengan mengenalkan pasangan calon yang di dukung kepada masyarakat melalui mimbar mimbar agama. Para kiai juga tidak sungkan mengajak pasagan calon dalam setiap agenda sosial kemasyarakatan baik diselengarakan oleh masyarakat sendiri.

Kedua kiai sebagai partisipan. Yaitu mereka yang sebenarnya masuk kedalam partai politik tertentu dan namanya tercantum dalam tim sukses. Namun, mereka tidak secara terbuka mengempanyekan pasangan calon yang didukung. kiai ini berpegangan bahwa masyarakat pada dasarnya mengetahui dan mengikuti dengan sendiri mengenai pilihan politik kiai. Kiai model ini juga mempersilakan dan mendorong mesin politik (kader partai) bergerak lebih banyak daripada dirinya. Hal ini peran kiai sebagai pemimpin agama tetap terjaga dengan baik.

Kiai dengan karismanya mampu menggeraknya kesadaran masyarakat dalam menentukan pilihan. Karismanya ini juga merupakan tipe kepemimpinanan yang sumber wewenangnya berasal dari kualitas pribadi sang pemimpin baik penampilannya yang agung dan diri pribadinya yang popular. Ia merupakan orang yang memperoleh anugrah istimewah dari suatu kekuatan supernatural sehinggah dapat menimbulkan daya pesona dan daya tarik bagi masyarakat. (Surbakti, 1992) Hal ini dikarenakan, pola hubungan kiai dan masyarakat yang sangat erat, merupakan faktor penting dan berfengaruh dalam menentukan pilihan politik. Hal ini juga di dasarkan pada fakta hubungan masyarakat dan Kiai tidak hanya terbatas pada saat berada dalam dunia tempat ibadah ( Majelis Taklim).

Kiai sebagai elit lokal mempunyai karakteristik tersendiri dalam memberi dukungan. Kiai dengan massa yang sangat hormat kepadanya mampu mendorong atau mendukung suara kemenangan untuk calon Bupati atau Wakil Bupati. Sebagai imbalan atas jerih payah kiai, Kepala Daerah (Bupati atau Wakil Bupati ) akan memberikan berbagai fasilitas, implikasi politik yang adaberpengaruh terhadap pilihan politik rakyat yang sudah dipengaruhi oleh berbagai macam iming-iming, tidaklah lagi otonom karena hak yang seharusnya lebih banyak dimanfaatkan oleh rakyat sebagai cerminan dari 
kedaulatan teracuni berbagai kepentingan materi dan kekuasaan. Tarik menarik "kepentingan"antara kandidat dengan kiai menjadi hal yang wajar. Hal ini dikarenakan, posisi kiai sangan menentukan keberhasilan seorang calon Kepala Daerah. Kiai dengan karismanya mampu memobilisasi masa dalam rangka penggalangan massa untuk berkampanye.

Ketika kiai masuk dalam sitem politik memulai parpol, secara otomatis kiai mendapat jatah untuk menjadi tim sukses atau juru kampanye calon yang didukung oleh parpol yang bersangkutan. Bermodal basis massa dan karisma, kiai mampu memainkan peran penting dalam suksesi seorang Kepala Daerah. Selain kiai terjun langsung ke gelanggang politik, ada kiai yang hanya menjadi partisipan atau hanya memberi restu kepada calon tertentu. Keadaan ini sebagai antisipasi perkembangan tempat Ibadah dan masa depan karir kiai jika ternyata calon pendukung kalah dalam pilkada. Kiai tidak terlibat dalam kegiatan politik secara langsung, Ia hanya menjadi pendukung di garis belakang. Artinya, tidak menjadi tim sukses atau juru kampanye calon tertentu. Keterlibatan Kiai dalam politik hanya sebatas pemberian restu kepada calon yang datang dan memohon restu ke tempat Majelis Taklim. Lebih lanjut, pemberian restu tidak hanya diberikan kepada satu calon saja, melainkan ketika ada calon yang datang ketempat sang Kiai dengan rela memberi restu untuk maju dalam Pilkada.

Kehidupan masyarakat desa sangat dipengaruhi oleh kebudayaan yang ada dan diakui sebagai sistem peraturan hidup bagi mereka. Seperti yang dikemukakan oleh Malvillie J.Herkovits dan Bronislaw Malinowski dalam buku Sosiologi Suatu Pengantar karangan Soerjono Soekanto, bahwa Cultural Determinism berarti segala sesuatu yang terdapat di dalam msyarakat ditentukan adanya oleh kebudayaan yang dimiliki oleh masyarakat itu. Dengan adanya kebudayaan telah mempengaruhi cara pandang , keyakinan dan kapatuhan bagi masyarakat desa. (Soekanto, 2001)

Didalam diri seorang kiai terdapat unsur cindekiawan, pemuka agama,pahlawan,serta jaringan ke pusat kekuasaan. Dalam buku karya Rosehan Anwar dan Andi Baharudin Malik terdapat setidaknya tiga peran ulama yang pertama yaitu kiai sebagai sekelompok cendekiawan dimana sebagian besar mereka ,dilahirkan dalam lingkungan, pendidikan, maupun pondok pesantren. Para Kiai tersebut ikut berperan dalam memajukan pendidikan dan ilmu pengetahuan. Peran kiai yang kedua adalah sebagai pembaharuan dalam agama islam. Pembaharuan yang dimkasud adalah dalam konteks kemasyarakatan, pendidikan, dan pemikirn seperti organisasi. Peran ulama yang ketiga adalah sebagai pengerak masyarakat seperti motivator,inspirator,katalisatot dan dinamisator. (Malik, 2003)

Kecamatan SP.Padang merupakan salah satu kecamatan yang terletak di Kabupaten Ogan Komering Ilir, memiliki penduduk yang mayoritas beragama islam. Dengan mayoritas beragama islam maka mempengaruhi kehidupan masyarakat,sebagai bukti ketika akan melakukan suatu kegiatan pembangunan atau kegiatan-kegiatan penting lainya baik sebelum maupun sesudahnya,masyarakat SP.Padang selalu mengadakan ritual-ritual keagamaan berupa pengajian atau thalilan.Dengan 
mengadakan ritual keagamaan ini diharapkan ketika memulai kegiatan akan di berkahi oleh Tuhan Yang Maha Esa dan dengan harapan akhir kegiatan bisa bermanfaat bagi anak, cucu, dan keturunan khususnya, dan bagi seluruh masyarakat pada umumnya.

\section{TINJAUAN LITERATUR}

Dalam penelitian ini, ada beberapa literatur yang penulis jadikan sebagai acuan dalam tinjauan pustaka. Tinjauan pustaka ini bertujuan untuk menemukan sisi menarik atau sisi lain dan kegunaan dari penelitian yang sedang penulis teliti. Beberapa tujuan pustaka yang penulis ditemukan sebagai instrumen perbandingan dalam melakukan penelitian mengenai keterlibatan ulama dalam politik studi. Terhadap ulama dan pengaruh terhadap partisipasi pilihan politik di masyarakat Kecamatan SP Padang Kabupaten OKI.

Pertama skripsi berjudul "Kiai sebagai Kekuatan Politik (Studi Kasus keterlibatan Kiai Dedy Suhandi pada pilkada kabupaten serang 2010) ’karya Sudirman alumni FISIP UIN Syarif Hidayatullah Jakarta yang lulus pada 2010. Ulama dalam politik perbedaannya adalah Sudirman menggunakan konsep kekuata n politik,berbeda dengan skripsi ini yang menggunakan otoritas karismatik dan konsep peran dan pengaruh, jadi penelitian ini berbeda denga penelitian yang sebelumnya.

Kedua skripsi ini berjudul "Peranan Cendekiawan dalam Transisi Demokrasi Era Reformasi: Telaah Gagasan Politik Amien Rais dan Nurcholish Madjid"Karya Akhmad Baizuri yang lulus FISIP UIN Syarif Hidayatullah Jakarta 
pada 2010. Dalam beberapa skripsi ini ulama dan Cendekiawan diletakkan dalam satu golongan,jadi persamaan skripsi ini dan skripsi Akhmad adalah sama-sama membahas peranan cendekiawan (umum maupun agama) dan keterlibatan politik dalam politik indonesia. Perbedaannya adalah kalau khmad pada reformasi sedangkan skripsi ini ulama dan pengaruh terhadap pilihan politik.

Ketiga, Skripsi berjudul 'Kepemimpinan Karismatik: Studivtentang Kepemimpinan Politik Megawati SoekarnovPutri dalam Partai Demokrasi Indonesia Perjuangan (PDIP)'. Karya Hadi Mustafa yang merupakan lulusan FISIPvUIN Syarif Hidayatullah Jakarta tahun 2011, Walaupun dari judul sudah terlihat perbedaanya yakni srkipsi Hadi secara jelas membahas Megawati dalam PDIP, namun terdapat persamaan yakni sama-sama menganalisis menggunakan konsep kepemimpinan karismatik.

Keempat, skripsi berjudul 'Peranan Kiai Terhadap Pengambilan Keputusan Pemilihan Dalam Pemilukada Tahun 2013 Kabupaten Pemekasan'. Karya Imrotul Hasanah yang merupakan lulusan dari Universitas Negeri Malang tahun 2013, walaupun judul sudah terlihat perbedaanya yakni skripsi Imrotul Hasanah membahasa peranan kiai terhadap pengambil keputusan pimilukada, namun terdapat persamaan yakni sama-sama menganalisis menggunakan kosep kepemimpinan dan peranan kedudukan Kiai yang sangat dibutuhkan oleh masyarakat.

Kelima, skripsi berjudul 'Peran Kiai Dalam membangun Partisipasi Pemilihan' Karya Nurhadi Sunarso yang merupakan lulusan dari Universitas Negeri Yogyakarta, walaupun judul sudah terlihat perbedaannya yakni skripsi Nurhadi Sunarso membahas peranan Kiai dalam membangunvpartisipasi pemilihan,vnamun terdapat persamaan yakni sama sama menganalisis menggunakan kepemimpinan karismatik.

\section{METODE PENELITIAN}

Istilah metode penelitian terdiri atas dua kata, metode dan penelitian.Metode berasak dari bahasa Yunani yaitu Methodos yang berarti cara atau jalan untuk mencapai sasaran atau tujuan dalam pemecahan suatu malasah. Dalam artian suatu usaha untuk mencapai sesuatu dengan metpde tertentu, dengan cara hati-hati, sistematik dan sempurna terhadap permasalahan yang dihadapi. Jadi metode penelitian adalah suatu cara dalam hal pemecahan terhadap suatu masalah yang sedang dihadapi.

Ditinjau dari segi tempat penelitian, meliputi penelitian di lapangan (field research), penelitian di perpustakaan (Library research), dan penelitian di laboratorium (laboratory reseacrh), penelitian di lapangan (field reseacrh), penulis terjun kelapangan kepada kiai yang terjun kedunia politik praktis, kiai lokal di KAB OKI Kecamatan SP.Padang. Melalui wawancara dan dokumentasi. Guna memperoleh data yang akurat. Selain itu, dalam penelitian sendiri yang harus memperhatikan hubungan antara objek dan dirinya sendri. 
Penelitian perpustakaan (library reseach) adalah penelitian yang menggunakan data dan informasi dengan namtuan bermacam-macam meteri yang terdapat dalam kepustakaan. Penelitan di laboratorium (laboratory resacrch) adalah penelitian yang dilaksanakan pada tempat tertentu atau laboratorium, biasanya eksperimen atau percobaan.

\section{HASIL DAN PEMBAHASAN}

Penelitian ini dilakukan pada tanggal 26 juli 2020. Penelitian dilaksanakan di Kecamatan SP.Padang Kabupaten Ogan Komering Ilir dengan menggunakan data-data yang relevan yang di dapat dari orang yang terlibat dalam Pilkada OKI di Kecamatan SP.Padang. Kemudian peneliti mewawancarai narasumber yang dirasa paham tentang data yang diperlukan untuk membahas penelitian dilakukan.

Secara figur dan personaliti, kiai dianggap sebagai kelompok agamis yang mengerti isu keagamaan secara mendalam dan spesifik serta sebagai penjaga moral dan akhlak. Para kiai umumnya memiliki basis massa seperti pesantren, sekolah-sekolah islam, dan pengikut setia yang tersebar di berbagai wilayah. Dua hal inilah yang menjadi faktor pendukung mengapa kiai selalu memiliki daya tarik politik baik hanya direkrut sebagai anggota partai mampu terjun sebagai tim sukses dalam Pilkada dan Pemilu.

Ada beberapa alasan dan argumentasi mengapa kiai terjun kedalam politik praktis. Pertama, hal ini dianggap sebagai panggilan dakwah mereka. Sebagai kiai berpandangan bahwa menjadi sholeh sendiri belumlah cukup, karena itulah mereka harus terjun dalam lingkup yang lebih luas, salah satunya politik. Para kiai menjadikan rahna politik sebagai medan dakwah yang lebih luas untuk menyampaikan kebaikan. Para kiai berharap kebaikan dan nilai yang mereka dapatkan dapt tertular tentuny dalam konteks politik.

Kiai dinilai menjadi faktor yang cukup efektif sebagai pendukung utama dalam Pilkada dan Pemilu. Pasca reformasi partai islam seperti PKB dapat bertahan, karena mereka punya basis yang kuat yakin kiai. Di daerah Jawa misalnya, para kiai yang bergabung dalam PKB memiliki banyak pesantren yang tersebardi banyak tempat. Hal ini membedakan bahwa kiaicukup signifikan untuk mendongkark partai politik tertentu.

Kecamatan SP.Padang Kabupaten Ogan Komering Ilir termasuk kota di Sumsel. Tapi pada saat yang sama suasana kebatinan dan kebangsaannya masih seperti di kampung-kampung dimana tokoh tradisional masih dianggap tokoh kunci dalam menyampaikan kebaikan.

Pada saat Iskander SE menjadi BUPATI OKI priode tahun lalu. Iskandar SE bukan hanya dianggap sebagai BUPATI OKI tapi juga sebagai alim ulama oleh 
masyarakat. Ini membuktikan walaupun Kabupaten Ogan Komering Ilir sudah menjadi modern, namun daya tarik Kiai masih sangat besar bagi masyarakat. Kota boleh saja modern tapi nilai keagamaan rupanya tak bisa dilepaskan dari kehidupan sosial maupun politik. Hal ini di perjelaskan oleh Pak Arnado .

"Saya kira respon kiai cukup kuat, Kabupaten OKI di Kecamatan SP.Padang inikan termasuk Kabupaten yang modern, maju di Sumsel. Tapi pada saat yang bersamaan susasana kebatinan dan kebangsaanya itu masih agak kampung karena masyakatnya masih urban dimana misalnya tokoh tradisional seperti kiai itu dianggap sebagai tokoh kunci untuk menyampaikan kebaikan. Meskipun Kecamatan SP.Padang Kabupaten Ogan Komering Ilir ini maju, ada kampus UNISKI dan Infrastrukturnya juga modern tapi KAB OKI ini karena dia menjadi bagian dari Sumsel,masyarakat cukup religius. Boleh modern tapi nilai-nilai keagamaan tidak bisa dilepaskan dalam kehidupan sosial politik mereka dan kita bisa lihat secara umum bahwa sumsel itu nuansa keislamannya cukup kuat karena sumsel ini dianggap sebgai tempat terakhir dimana ajaran islam itu disebarkan. Makanya kemudian sentimen dibanyak tempat disumsel cukup kuat termasuk di KAB OKI. Bukti nyata adalah kenapa misalnya,terpilihnya Iskandar SE Pada priode pertama secara berturut-turut jadi Bupati OKI. Itu bukti bahwa keterlibatan Kiai dalam Pilkada OKI sangat berpengaruh. Masyarakat cukup Relegius bahwa modernitas tidak serta merta menghilangkan nilai-nilai kegamaan yang dimiliki oleh masyarakat KAB OKI . Biasanya kalau orang sudah modern nilai agama cenderung ditinggalkan dan akan cenderung lebih memilih pimpinan sekuler, pimpinan yang tidak beririsan dengan agama. Tapi di OKI karena tinggal di Sumsel nuansa religiussitasnya tidak bisa dihilangkan begitu saja. Boleh modernvtapi nilai agama masih menjadi suatu hal yang harus diperhatikan oleh mereka, sebab itulah figur-figur yang ada di KAB OKI selama kontestasi yang pernah ada kalo saya cek, ustad-ustad itu ataupun terindikasi memiliki paham kegamaan ulama tertentu itu biasanya memiliki daya tarik bagi masyarakat KAB OKI . beda dengan kota lain , di kota lain biasanya kiai tidak terlalu menjadi daya tarik ataupun tidak terlalu laku, karena masyaraakat sudah sekuler. Agama sudah mulai di coba untuk dipisahkan, atribut-atribut agama mencoba untuk dijauhkan dari hal-hal politik.

Tabel pemilihan dan pengguna hak pilih Kabupaten OKI

\begin{tabular}{|l|l|l|l|l|}
\hline No & $\begin{array}{l}\text { Pemilih dan pengguna } \\
\text { hak pilih }\end{array}$ & Laki-laki & Perempuan & Total \\
\hline 1 & Pemilih & 245.042 & 231.821 & 476.863 \\
\hline 2 & Pengguna hak pilih & 145,083 & 138,567 & 283,65 \\
\hline
\end{tabular}




\begin{tabular}{|l|l|l|l|l|}
\hline 3 & Partisipasi & $53,13 \%$ & $59,43 \%$ & $56,84 \%$ \\
\hline
\end{tabular}

\section{Sumber:KPUD KAB OKI}

Melihat tabel di atas, jumlah suara sah pengguna hak pilih masyarakat KAB OKI laki-laki maupun permpuan yaitu 476.863 suara,sedangkan jumlah suarah tidak sah pada pemilukada kab oki tahun 2018 yaitu 29.091 suara. Dapat dikatakan bahwa sekitar 95,80\% suara dinyatakan sah oleh komisi pemilihan umum KAB OKI.

Terdapat sejumlah peranan kiai yang turut andil dalam hasil penghitungan tersebut. Hal ini diperkuat dengan temuan penulisan lapangan dalam wawancara singkat dengan tim pasangan calon pada tahun 2018.

Dari data survei terakhir yang dilakukan terdapat pasangan berbeda pasangan Iskandar SE 37\% dan masih ada masyarakat sekitar 20\% yang belum menentukan pilihan . sementara dalam sejarah pilkada untuk $20 \%$ orang yang belum menentukan pilihan itu sulit bagi pasangan calo untuk meraup 20\%nya. Yang paling bisa maksimum dengan bekerja keras. Mati-matian, bagikan duit dan lain sebagaimananya paling hanya akan mendapatt $10 \%$. Tatapi kenyataan seolah-olah $20 \%$ pemilihan yang mengambang ini lari ke ISKANDAR SE, dan tidak terlepas dari dukungan-dukungan kiai. Itu jugavyang dikatakan oleh pak dimas pada sesi wawancara, pertanyaannya sama"apa penyebab yang membuat anda kalah pada pemilu?" jawabannya sama yaitu isu agama . saya mendengarkan itu, selain itu, hal ini juga diperkuat dengan temuan penulisan dilapangan dengan melakukan wawancara pribadi.

Selain karena faktor incumbent, sekitar 40\% kemenangan Iskandar SE karena ada pula dukungan ulama (kiai) bahkan beliau mendeklarasikan untuk mendukung pak Iskandar, tapi saya tidak bisa menyebutkan namanya, yang jelas para ulam kiai inivpunya pengikut sebagaimana pemilukada, saya fikir sangat wajar karena ini merupakan bagian dari dimanika, dari sebuah proses demokrasi, pesta demokrasi, bagaimana kita saling mempengaruhi pemilih untuk memilih kita.

\begin{tabular}{|c|c|c|c|c|c|c|c|c|c|c|}
\hline \multirow[t]{3}{*}{ Kecamatan } & \multicolumn{10}{|c|}{ Daftar Pemilih Pilkada 2018} \\
\hline & \multirow{2}{*}{$\begin{array}{l}\text { Jml } \\
\text { Tps }\end{array}$} & \multicolumn{3}{|c|}{ Jumlah Pemilih } & \multicolumn{6}{|c|}{ Difabel } \\
\hline & & $\mathrm{L}$ & $\mathrm{P}$ & Total & 1 & 2 & 3 & 4 & 5 & Total \\
\hline Air Sugihan & 94 & 11.415 & 10.317 & 21.732 & 6 & 5 & 5 & 2 & 1 & 19 \\
\hline Cengal & 109 & 9.842 & 8.404 & 18.246 & 1 & 3 & 3 & 1 & 0 & 8 \\
\hline Jejawi & 107 & 15.064 & 14.431 & 29.495 & 4 & 6 & 2 & 1 & 8 & 21 \\
\hline Kayu agung & 138 & 22.483 & 22.768 & 45.251 & 8 & 2 & 7 & 2 & 5 & 24 \\
\hline
\end{tabular}




\begin{tabular}{|c|c|c|c|c|c|c|c|c|c|c|}
\hline Lempuing & 161 & 24.154 & 22.452 & 46.060 & 5 & 1 & 5 & 1 & 7 & 19 \\
\hline $\begin{array}{l}\text { Lempuing } \\
\text { jaya }\end{array}$ & 140 & 19.830 & 17.719 & 37.549 & 4 & 1 & 5 & 2 & 0 & 12 \\
\hline Mesuji & 80 & 13.166 & 12.642 & 25.808 & 1 & 0 & 0 & 0 & 1 & 2 \\
\hline $\begin{array}{l}\text { Mesuji } \\
\text { makmur }\end{array}$ & 114 & 18.754 & 17.487 & 36.214 & 10 & 6 & 3 & 0 & 5 & 24 \\
\hline Mesuji raya & 90 & 11.664 & 10.886 & 22.550 & 12 & 8 & 6 & 12 & 1 & 39 \\
\hline Pampangan & 82 & 9.405 & 9.357 & 18.762 & 2 & 2 & 11 & 1 & 2 & 18 \\
\hline $\begin{array}{l}\text { Pangkalan } \\
\text { lampam }\end{array}$ & 56 & 8.303 & 8.289 & 16.592 & 0 & 0 & 0 & 0 & 0 & 0 \\
\hline Pedamaran & 99 & 13.207 & 13.235 & 16.592 & 4 & 2 & 2 & 0 & 7 & 15 \\
\hline $\begin{array}{l}\text { Pedamaran } \\
\text { timur }\end{array}$ & 47 & 6.913 & 6.382 & 26.442 & 2 & 6 & 9 & 1 & 1 & 19 \\
\hline $\begin{array}{l}\text { Sirah pulau } \\
\text { padang }\end{array}$ & 120 & 14.668 & 14.323 & 13.295 & 18 & 1 & 5 & 1 & 4 & 29 \\
\hline $\begin{array}{l}\text { Sungai } \\
\text { menang }\end{array}$ & 118 & 13.522 & 11.500 & 28.991 & 1 & 0 & 0 & 2 & 0 & 3 \\
\hline $\begin{array}{l}\text { Tanjung } \\
\text { lubuk }\end{array}$ & 93 & 11.312 & 10.894 & 25.022 & 3 & 6 & 6 & 2 & 5 & 27 \\
\hline Teluk gelam & 54 & 8.133 & 8.120 & 16.253 & 6 & 0 & 3 & 1 & 3 & 13 \\
\hline $\begin{array}{l}\text { Tulung } \\
\text { selapan }\end{array}$ & 116 & 13.207 & 12.615 & 25.822 & 3 & 4 & 5 & 2 & 2 & 16 \\
\hline Total & $\begin{array}{l}1.81 \\
8\end{array}$ & $\begin{array}{l}245.04 \\
2\end{array}$ & $\begin{array}{l}231.82 \\
1\end{array}$ & $\begin{array}{l}476.86 \\
3\end{array}$ & 90 & 53 & 77 & 31 & 52 & 303 \\
\hline
\end{tabular}

Sumber:Badan pusat statistik KAB OKI

\section{Pola Keterlibatan Kiai Dalam Politik}

Kiai merupakan figur elit lokal yang disegani oleh masyarakat . Hal ini karena kiai memiliki ilmu agama yang tinggi sehingga memunculkan kharismatiknya pada masyarakat. Figur kiai mengalami dimanika sosial dalam masyarakat yang selalu menarik untuk diperbincangkan.

Selain sebagai teladan bagi masyarakat, kiai dinilai sebagai sosok yang memiliki pengaruh dikalangan elit politik. Buktinya para kiai yang 
terlibat dalam politik praktis, selalu ditempatkan dalam posisi yang strategis. Meskipun kiai belum tentu mau ditempatkan sebagai pengurus partai politik. fenomena ini telah menjadi rahasia umum dikalangan elit politik sebagai strategi untuk mencari dukungan dari kalangan tradisional,umatnya dari kalangan pesantren juga. Alasanya kiai dinilai memiliki kantong-kantong suara atau massa pendukungnya, yaitu para santri dan dari kalangan masyarakat tradisional.

Keterlibatan kiai dalam politik bukan menjadi fenomena baru. Sejak zaman pra kemerdekaan sampai sekarang. Kiai merupakan sosok yang selalu terlibat dalam politik praktis. Meskipun kualitas dan kuantitasnya mengalami perbedaan dari zaman ke-zaman.

Berdasarkan wujud keterlibatan kiai dalam politik praktis di Kecamatan SP.Padang KAB OKI adalah sebagai berikut.

1. Keterlibatan kiai sebagai pengurus struktural partai politik, keterlibatan ini biasanya kiai dan ustadz secara langsung menjabat sebagai pengurus partai politik baik di tingkat lokal, wilayah, maupun nasional.

2. Keterlibatan kiai sebagai calon legislatif dan eksekutif seorang kiai atau ustadz dalam hal ini langsung mencalonkan diri atau dicalonkan oleh partai politik sebagai calon legislatif maupun eksekutif.

3. Keterlibatan kiai dalam bentuk dukungan suara dan kampanye wujud dukungan kepada calon yang dikehendaki baik secara langsung maupun tidak langsung. Secara langsung misalnya kiai secra terbuka mendukung partai politik, calon legislatif, maupun eksekutif. Sedangkan secara tidak langsung, biasanya para politisi memohon sendiri kepada kiai dengan cara minta do'a restunya serta memilih partai politik, calon lesgislatif,maupun eksekutif yang mereka inginkan.

Yang menjadi kajian ini adalah kiai dan ustadz yang mengajar, mengasuh, membimbing para santri dan sekaligus berkecimpung dalam dunia politik. vselain mempin pondok pesantran, mereka juga aktif dalam berbagai kegiatan sosial keagaman dan berbagai kegiatan lainnya. Tugas dan peran kiai sebagai pendidik para santri, ketika terjun dalam politik praktis, menyebabkan mereka melakukan peran ganda.

Keterlibatan mereka dalam politik praktis ternyata disamping sebagai pengurus partai politik, juga sebagai pendukung partai, pendukungvcalon legislatif,eksekutif, dan juru kampanye partai politik. Disamping itu mereka juga sering didatangi para politisi,calon anggota legislatif maupun eksekutif, untuk diminta dukungannya. Mereka juga dicatat sebagai juru kampanye salah satu partai politik. namun mereka sampai sekarang belum mempunyai niat untuk mencalokan diri sebagai calon legislatif maupun eksekutif. 


\begin{abstract}
Keterlibatan mereka dalam politik praktis, tidak bisa dilihat hanya sebagai kepentingan sesaat. Sikap tersebut memiliki keterkaitan dengan dimanika sosial politik yang sedang berkembang, dan juga berkaitan dengan konstalasi politik pada masa-masa sebelumnya.
\end{abstract}

Pada orde baru misalnya, kecendrungan arus politik yang sentralistik menjadikan kiai menghadapi dilema,khususnya saat berhadapan dengan pemerintahan. Segala aktifitas politik masyarakat, termasuk aktifitas politik yang dilakukan oleh kiai, dibatasi, atau bahkan dicurigai.

Realitas semacam ini dalam kenyataannya justru membawa dampak berupa kian kuatnya posisi kiai dalam konstalasi sosial kultural masyarakat. Kiai dan para ustadz yang masuk kategori ini adalah mereka yang benar-benar dekat menyentu dengan umat, membela mereka dari penyimpangan-penyimpangan yang terjadi, bahkan menjadi penegah dalam relasi antara rakyat dengan pemerintah.

Era reformasi membawa perubahan konstalasi politik secara fundamental. Bergilirnya angin reformasi yang kemudian diikuti dengan terbentuknya beberapa partai islam tampaknya memberi angin segar bagi kehidupan pondok pesantren yang dimonitori oleh para kiai.

Hal ini bukan saja kiai bebas memilih partai politik yang dikehendaki sajam namun akibat dari perubahan warna politik pada erareformasih sekarang ini, terjadi sebuah proses demoktasi dalam kehidupan pondok pesantren. Sebagai contoh adalah dalam kehidupan pondok pesantren Bait AL-Qur'an dan pondok pesantren Darul Muttaqien. Pondok pesantren ini telah mengalami proses demokrasi yang cukup sehat. Hal ini bisa dilihat dalam kehidupan politik yang terjadi di pondok pesantren tersebut. Antara kiai dan para ustadz yang mengajar, terdapat afilasi politik yang berbeda. Kiai memilih Partai Persatuan Pembangunan (PPP), sedangkan para ustadznya cukup bervariasi terhadap sikap politiknya. Ada yang mengikut jejak kiainya itu (PPP) sebagai partai politiknya, ada yang mengikuti partai politik lainnya,dan ada yang tidak memilih partai politiknya.

Mengenai hubungan politik antara pengasuh pesantrean dan para santri, para kiai dan ustadz tidak pernah memaksakan sikap politiknya kepada para santrinya. Santri dibebaskan dan dipersilahkan mengikuti partai politik sesuai denga hati masingmasing. Keterlibatan kiai dalam politik praktis membawa implikasi terhadap pesantrennya, khususnya minat belajar para santri juga, implikasi kiai berpolitik. Bagi pesantren ialah berkurangnya kesempatan kiai dalam membina pesantrennya. Hal ini disebabkan karena katifitas politik membuat para kiai tersebut harus sering keluar untuk koordinasi maupun kegiatan politik lainnya.

Secara khusus, keterlibatan kiai dalam politik membawa implikasi terhadap para santri. Hal ini disebabkan karena mereka kurang perhatian dari kiai. Dalam fenomena pemilukada KAB OKI tahun 2018 dapat dikorelisasikan bahwa kiai melibatkan diri dalam memberikan dukungan terhadap pasangan calon. 
Namun secara tidak terang-terangan. Dukungan yang diberikan dengan menyisipkan isi ceramah mereka dilembaga pendidikan,pesantren,maupun majelismajelis untuk memilih pemimpin yang berlatar belakang kiai (ulama). Gerakan para ulama ini lebih bertujuan untuk mengajak masyarakat memilih pemimpin yang baik agar kehidupan masyarakat lebih maslahat.

Otoritas merupakan bentuk dari hubungan kekuasaan sekaligus mengandung unsur perintah atau kontrol. Sedangkan karisma yang dimilikinya, namun otoritas ini tidaklah dapat dimiliki oleh setiap orang. Otoritas dapat hilang apabila seseorang tersebut memiliki melakukan kekeliruan atas kesalahan fatal yang bertentangan dengan norma sosial,norma hukum, norma adat,terlebih lagi norma agama,sehingga dapat mengakibatkan pandangan terhadap masyarakat ikut berubah.

Karisma yang dimiliki oleh kiai melahirkan otoritas yang sangat besar pengaruhnya ditengah-tengah masyarakat luas dan dengan sendirinya juga muncul respon kektaatan serta sikap hormat terhadap umat kepada kiai. Setiap pembicaran dan sikap kiai akan menjadi acuan atau refrensi umat untuk melakukan kegiatan yang sama. Hal ini bisa terlaksanakan karena kiai sudah memberikan peran yang nyata dalam kehiduapan masyarakat.

Sebagai suatu hubungan yang sangat kuat, segala hal yang diperintahkan oleh seseorang kiai maka dengan serta merta umat akan melakukan perintah tersebut. Kalau kita tertarik pernyataan ini kedalam wilayah politik praktis, sebagai contoh pemilukada di KAB OKI 2018. Maka dengan sangat mudah mendapatkan dukungan dan pilihannya pada pasangan calon tertentu dalam kontestasi dan kompetisi pemilukada tersebut maka umat akan mengikuti apa yang dilakukan oleh kiai (ulama) tersebut.

Kesamaan indentitas antara kandidat yang bersaing dalam pilkada dengan masyarakat sebagai pemegang hak pilih memang sedikit banyak mempengaruhi atas berjalannya proses demokrasi lokal tersebut. Terutama dalam hal menentukan pilihan politik dari pemilihan. Proses keterkaitan seseorang dalam kelompok atas dasar ikatan kekerabatan ,suku bangsa, kebahasaan dan adat istiadat sehingga melahirkan pola perilaku serta cita-citavyang sama. Kandidat politik dengan kiai menjadi suatu pembeda dan secara teoritis akan mempengaruhi prilaku politiknya.

Faktor personal dalam dunia politik bagi sebagian orang menjadi satu hal yang sangat berpengaruh. Bagi masyarakat awam yang memilih pemimpin karena melihat seorang diidolainya mengajak untuk mendukung salah satu pasangan calon tertentu. Konsekuensinya yaitu menjadi pendukung bersikap secara buta karena tidak melalui pertimbangan yang mendalam. Pentingnya sosok personal yang dianggap bisa mempengaruhi prilaku politi seseorang memang sisadari betul oleh setiap aktor politik. hal ini bisa kita cermati ketika partai-partai politik melakukan kampanye dengan mengandeng tokoh-tokoh seperti politisi,selebritis,hingga ustadz dan kiai. Tokah kiai tersebut diharapka dapat menjadi magnek tertentu untuk memangnet masyarakat. Kiai 
sebagai tokoh menjadu daya tarik tersendiri karena dikenal banyak kalangan bisa menyentuh lapisan masyarakat yang sedikit alergi terhadap dunia politik .

Kedekatan seorang kiai dengan politisi yang menghasilkan berbagai stigma ditengah masyarakat. Stigma positif timbul dengan opini bahwa kita bisa sedikit banyak merubah dunia politik yang dikenal kotor sehingga kiai bisa diharapkan untuk menjadi filter agar bisa manghasilkan suatu aktivitas politik yang baik. Opini tersebut berbanding terbalik dengan anggapan lain yang mengatakan bahwa kiai yang ikut terjun kedunia politik baik secara aktif maupun fasip, maka dia diibaratkan telah masuk kedalam sebuah kumbangan lumpur. Tanggapan yang lebih negatif adalah kiai tersebut pasti mengharapkan sesuatu dari tokoh politik yang didukungnya.

\section{KESIMPULAN}

Peranan kiai dalam mengahdapi pemilukada di Kabupaten Ogan Komering Ilir di Kecamatan SP.Padang ternyata sangat berpengaruh besar terhadap kemenangan salah satu pasangan calon yang menjadi dukungannya. Hal ini terbukti ketika dalam perhitungan suara pasangan calon yang berfigur sebagai kiai pesantren dan kiai dalam kalangan masyarakat mendapatkan suara terbanyak dari pasangan calon yang tidak berfigur kiai. Sebab masyarakat Kecamatan SP.Padang pada umumnya beranggapan bahwa ahklak seorang kiai masih terjaga dari pada orang yang bukan kiai. Selain itu peranan kiai dalam bidang politik sangat mempengaruhi preferensi politik masyarakat dalam pemilukada. Meskipun tidak semua masyarakat mengikutinya. Masyarakat yang mengikuti partai pilihan kiai biasanya masyarakat yang memiliki hubungan dekat dengan kiai dan sering mengikuti berbagai kegiatan bersama kiai.

Setelah reformasi tidak sedikit kiai yang tadinya hidup bertapa, khusyuk, dan tentram dalam pondok pesantren dan dalam kehidupan sepiritualnya menjadi haluan , menyebrangi dunia baru yang bernama vpolitik praktis. Beberapa wujud keterlibatan kiai dalam politik praktis yaitu keterlibatan kiai sebagai pengurus struktural partai politik, keterlibatan kiai sebagai calon legislatif dan eksekutif, keterlibatan kiai sebagai dalam bentuk dukungan suara dan kampanye.

Adapun faktor lain yang mempengaruhi keterlibatan kiai dalam politik praktis yaitu:

1. Faktor kekuasaan, meliputi cara-cara untuk mencapai hal yang diinginkan melalui sumber-sumber kelompok yang ada di masyarakat.

2. Faktor kepentingan, merupakan tujuan yang dikejar oleh pelaku-pelaku atau kelompok politik.

3. faktor kelembagaan, merupakan faktor kekeluargaan dan faktor individu dan antar individu

4. faktor ekonomi, termasuk faktor yang berpengaruh dalam mata pencaharian untuk kiai . 
5. budaya politik, merupakan orientasi subyektif individu terhadap sistem politik. kebudayaan politik sebagai orientasi nilai dan keyakinan politik yang melekat dalam diri individu dapat dianalisis dalam beberapa orientasi. Yaitu orientasi kognitif, afektif, dan orientasi evaluatif yang mendasari perilaku politik. 


\section{DAFTAR PUSTAKA}

Akhmad Baizuri, 2010, Peranan Cendekiawan dalam Transisi Demokrasi Era Reformasi Andrain Carless F, 1992, . Kehidupan Politik dan Perubahan Sosial,Yogyakarta:Tiara Wacana

Anwar Rosehan dan Andi Malik Bahrudin, 2003, Ulama dalam Penyebaran Pendidika dan Khanzanah Keagamaan.(Jakarta:Proyek Pengkajian dan Pengembangan Lektur Pendidikan Agama

Ariansyah, R., \& Masyhur, M. (\&nbsp;). Identitas Agama dan Pola Gerakan Sosial (Studi Kasus Front Pembela Islam Di Kota Palembang). Ampera: A Research Journal on Politics and Islamic Civilization, 1(1), 49-60. Retrieved from http://jurnal.radenfatah.ac.id/index.php/Ampera/article/view/5206

Arikunto Suharsimi, 1992, ,Prosedur Penelitian,Suatu Pendekatan Praktek, Jakarta: Rine. Arikunto Suharsimi, 2006, Proses Penelitian:Suatu Pendekatan Praktik, Jakarta: Rineke Cipta

Azra Azumardi, 2000, Islam di Tengah Aarus Transisi Menuju Demokrasi, dalam Abdul Mu'nim D.Z (Ed): Islam di Tengan Arus Transisi,Penerbit KOMPAS,Jakarta,Oktober 2000.

Budiharjo Miriam, 2008, ,Dasar-Dasar Ilmu Politik ,PT.Gramedia Pustaka Utama , Jakarta

Bungin Burhan, 2014, Metodologi Penelitian Kuantitatif ,Jakarta: Kencana Prenada Media Group

Fajri Ahmad, 2015, Ulama dan Politik, Tanggerang :Kenanga Pustaka Indonesia

Giddens Anthony, 1986, Kapitalisme Dan Teori Sosial Moderen,Jakarta:Universitas Indonesia Press

Hasanah Imrotulah, 2013, Peranan Kiai Terhadap Pengambilan Keputusan Pemilihan Dalam Pemilukada Tahun 2013 Kabupaten Pemekasan Malang UM

Mikail, Kiki. "PEMILU DAN PARTAI POLITIK DI INDONESIA: Menanti Kebangkitan Partai Politik Islam Di Tahun 2019". Tamaddun: Jurnal Kebudayaan dan Sastra Islam 15, no. 1 (April 7, 2016): 107-148. Accessed January http://jurnal.radenfatah.ac.id/index.php/tamaddun/article/view/444. 